\section{ECCOMAS}

\section{Proceedia}

COMPDYN 2021

$8^{\text {th }}$ ECCOMAS Thematic Conference on Computational Methods in Structural Dynamics and Earthquake Engineering

M. Papadrakakis, M. Fragiadakis (eds.) Streamed from Athens, Greece, 28 - 30 June 2021

\title{
DERIVATION OF SEISMIC FRAGILITY CURVES OF A GRAVITY- LOAD DESIGNED RC SCHOOL BUILDING THROUGH NLTHA
}

\author{
E. Saler ${ }^{1,2}$, P. Carpanese ${ }^{2}$, V. Follador ${ }^{2}$, and F. da Porto ${ }^{2}$ \\ ${ }^{1}$ Dept. of Civil, Environmental and Mechanical Engineering, University of Trento \\ Via Mesiano 77, 38123 Trento, Italy \\ e-mail: elisa.saler@unitn.it \\ ${ }^{2}$ Dept. of Geosciences, University of Padova \\ Via Gradenigo 6, 35131 Padova, Italy \\ pietro.carpanese@phd.unipd.it; \{veronica.follador,francesca.daporto\}@unipd.it
}

\begin{abstract}
School buildings are considered relevant structures and their safety towards seismic actions shall be verified in consideration of the significant consequences of their collapse. With reference to Italy, most reinforced concrete (r.c.) schools were built after the second world war and in the later years of the economic boom, before a widely applied seismic regulation. In fact, seismic classification of Italy was a long process developing throughout the XX century, with significant areas which were not considered seismic until the early 2000s.

The paper presents the evaluation of the seismic behavior of a representative 2-story Italian r.c. school building designed for gravitational loads only, and the derivation of a fragility curve set describing the seismic behavior of the macro-class of buildings. A series of NonLinear Time History Analyses (NLTHA), with sets of natural ground motion records of increasing intensity, were implemented on two fiber models, developed in Midas GEN, representing the bare frame $(B F)$ and the infilled frame (IF) configurations, respectively. Interstory drift ratio (IDR) was chosen as demand parameter to identify the Damage State (DS) exceeded by each analysis and explicitly calculated for the analyzed structure. Fragility curve sets, describing five increasing DSs, were derived, for both the BF and the IF configurations, through the statistical processing of NLTHA results. A comparison of the calculated fragilities, between BF and IF models, is finally provided.
\end{abstract}

Keywords: Fragility curves, school buildings, RC frame, gravitational load design, Nonlinear time history analysis. 


\section{INTRODUCTION}

Italy is one of the most seismic prone countries of Europe, where earthquakes have caused casualties, unusable buildings, huge economic losses for both the residential [1,2] and the industrial $[3,4]$ assets, and damage to the cultural heritage with heavy repercussions on the tourism sector [5]. Furthermore, the global impact of strong seismic events on communities is hardly quantifiable. In this framework, schools play a crucial role due to the high social impact of their collapse, threatening children and youth, and their unusability in the aftermath of a seismic event [6,7]. Thus, an estimation of seismic risk and damage scenario related to school buildings is required to deepen knowledge of disaster risk (Priority 1 of the Sendai Framework for Disaster Risk Reduction 2015-2030 [8]).

With this aim, a national project has been established by the Italian Department of Civil Protection (DPC) and the Laboratories University Network of seismic engineering (ReLUIS consortium), to develop maps of seismic risk and damage scenarios for different classes of buildings (e.g., ordinary buildings, schools, and churches) at a national scale [1,9].

Risk estimation requires the definition of hazard, exposure and vulnerability of the built asset. Various methodologies have been developed to assess vulnerability at large scale, and they are mainly based on the derivation of fragility curves (i.e., cumulative density function expressing the probability of exceeding a damage state). Empirical approaches provide the description of damage probability (through damage probability matrices - DPM) based on the post-event observed damage [10-13]. These methods provide realistic fragility estimates, which however strongly depend on collected data, and thus on the building taxonomy of the region interested by the seismic event. Lack of damage data (e.g., for certain levels of seismic intensity or for specific building types) can be overcome using hybrid methods [14,15], based on both empirical data and mechanical models, of which some examples are presented as follows. Numerous studies have focused on developing fragility curves by means of mechanics models. Among the others, mechanics-based vulnerability assessment of structures can be based on simplified procedures [16-19], including Displacement-Based approaches [20-22], as well as on non-linear time history analyses (NLTHA) $[23,24]$.

This contribution provides a proposal of vulnerability assessment of a specific class of school buildings (i.e., two-story r.c. frame designed for gravitational loads only), by deriving fragility curves through NLTHA performed on a finite element (F.E.) model of a prototype school. To investigate the influence of infills on the seismic response, two different models were implemented to simulate the dynamic behavior of both bare frame (BF) and infilled frame (IF).

Seven ground motion suites, each consisting of 10 accelerograms, were selected based on spectrum-similarity criteria, with reference to the elastic spectrum of L'Aquila, Italy, for seven increasing return periods. The investigated demand parameter was the interstory drift ratio, which was associated to damage states (DSs) through threshold values from the literature $[9,25]$. Then, the statistical processing of NLTHA outcomes was carried out to estimate the parameters (i.e., median value and standard deviation) of the log-normal cumulative density function (CDF), allowing fragility curves to be derived, and then compared.

The IF model shows a regular distance among DS fragility curves, while the slightly higher ductility of the BF configuration is found in the distribution of fragility curves, resulting more spaced.

\section{ITALIAN SCHOOL BUILDING ASSET}

The reference dataset for the risk assessment at national scale is the Italian school building registry (SBR) of the Ministry of Education [26] which gathers almost 50,000 school build- 
ings, of which 16,522 are r.c. structures. School buildings are registered on the basis of a limited number of parameters: construction material and age, number of stories, plan area, and types of floors and roof. The distributions of typological characteristics of the r.c. schools are reported in Figure 1. Reinforced concrete schools result to be built mainly after 1961, with a prevalence of low-rise structures, with one or two stories. Similarly, the distribution of plan area shows a prevalence of small to medium buildings, up to $2,000 \mathrm{~m}^{2}$. However, the amount of larger buildings is not negligible, and moreover they present a significant exposure.
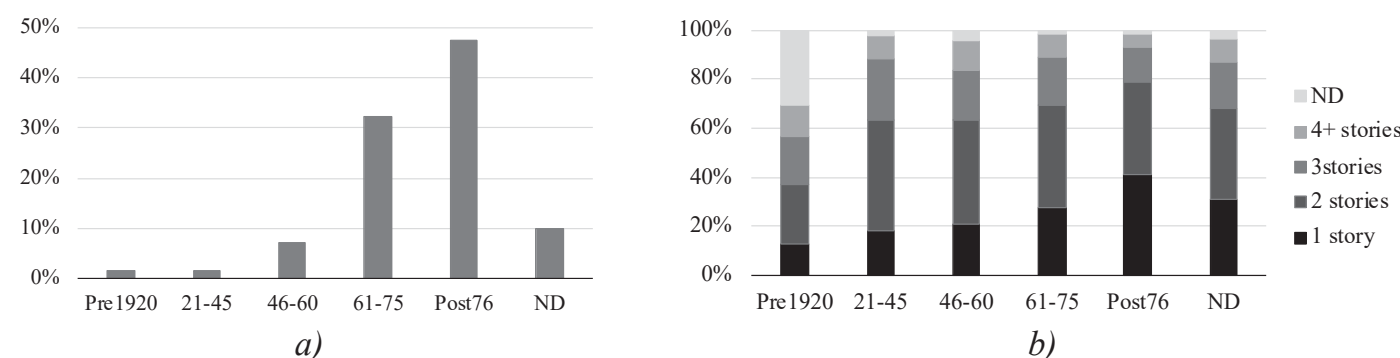

b)

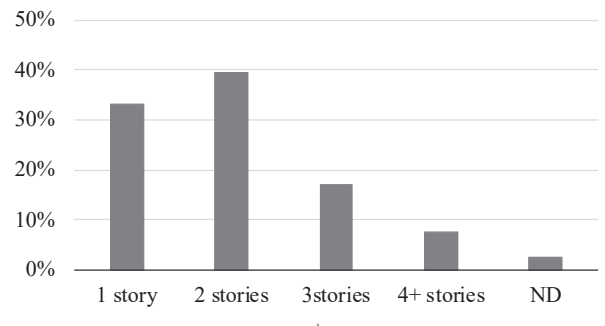

c)

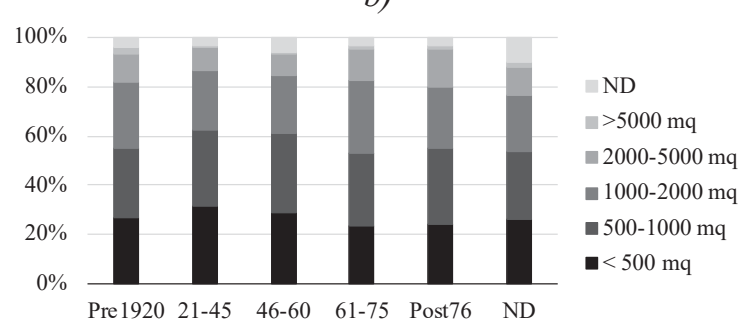

d)
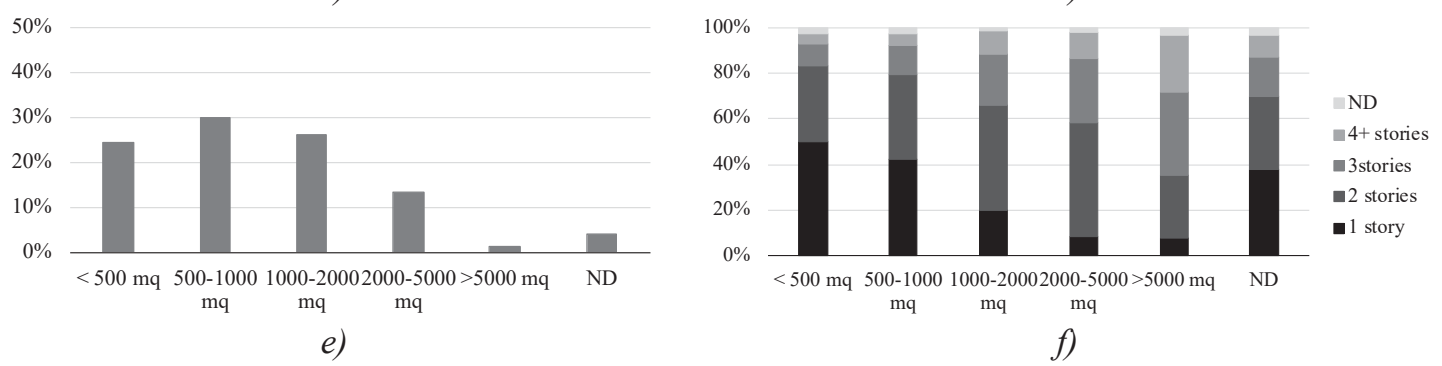

Figure 1: Typological characteristics of r.c. buildings in Italian SBR: a) construction age; b) number of stories given age; c) number of stories; d) plan area given age; e) plan area; f) number of stories given plan area

The processing of the dataset allowed the identification of a series of macro-classes adequate for risk analyses at a national scale, i.e., based on a limited number of parameters which distribution is available on the country (construction material, number of stories, and age). Each macro-class is assumed to be homogeneous from a seismic vulnerability point of view; thus, a single set of fragility curves, describing the probability of exceeding various damage states, can be assigned to each macro-class. Fragility models of macro-classes can be developed through the analysis of prototype structures, selected on the basis of representativeness criteria, so that results can be extended on a national scale.

This paper presents, as case study, the fragility assessment for a prototype r.c. school, representative of the macro-class of two-story school buildings built between 1961 and 1975 .

\subsection{Selected prototype r.c. school building}

The selected school building consists in a two-story r.c. bi-directional frame (weak columns/strong beams), designed in 1966 for gravitational loads only. The retrieved original project documentation reported both the detail of reinforcement for each structural element and 
the class of smooth rebars (i.e., AQ50), while no data was found regarding the concrete class. Thus, a mean cylinder compressive strength $\left(f_{c m}\right)$ equal to $20 \mathrm{MPa}$ was assigned according to Masi et al. [27].

The school, which plan is shown in Figure 2, presents significant openings on the façades of classrooms, with five bays of the frame entirely infilled with hollow clay bricks with modest void area, approximately equal to $35 \%$ (Figure 3). Infills panels are $13 \mathrm{~cm}$ thick (one header).

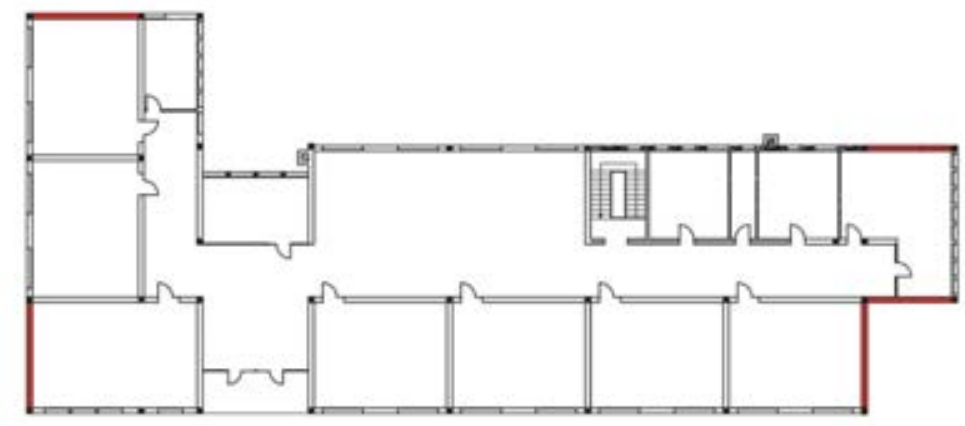

Figure 2: School plan with indication of infilled bays (in red).
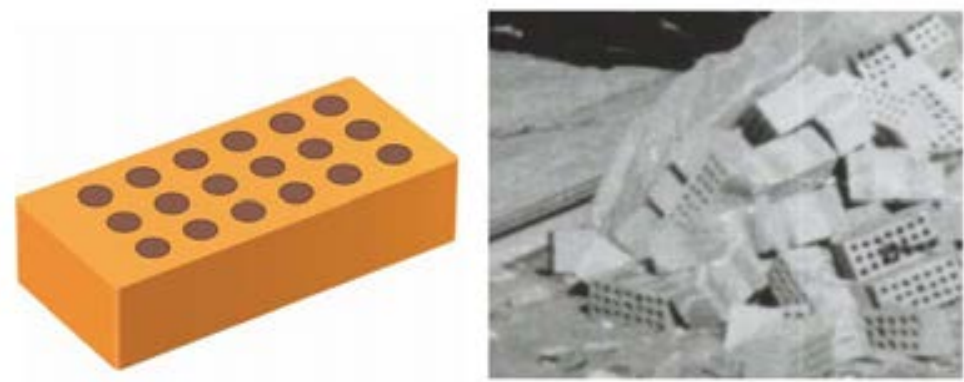

Figure 3: Hollow clay brick used for infill panels and photo of coeval school construction site.

\section{FRAGILITY ASSESSMENT THROUGH NLTHA}

\subsection{Modelling of bare frame and of masonry infills}

Two numerical models of the prototype building were implemented through the software Midas GEN [28]. For r.c. structural elements a fiber model [29] was developed, on the basis of the original project documentation. The constitutive laws of materials were assumed according to Mander [30] for concrete, accounting for confinement, and Menegotto and Pinto [31] for steel, considering an hardening behavior.

To investigate the influence of infills on the global behavior of the structure, two different models were implemented: a first one simulating the bare frame, and a second one representing the infilled frame (as shown in Figure 4a).

Prior studies have experimentally defined the seismic response of both thin masonry infills [32-34] and thick panels [35,36], with reference to hollow blocks with high void area. Thus far, no experimental data were available on masonry infill walls with low void area. The seismic behavior of masonry infills is affected by the interaction of in-plane (IP) and out-ofplane (OOP) responses. Some detailed models have been developed to catch this combined effect through numerical simulations [37,38], however, up to now, hardly appliable to fragility assessment. 
For the purposes of this study, a single-strut macro-model was implemented for infill panels, as it allows an efficient simulation of the infill influence on the global structural behavior, with limited numerical effort [39]. The equivalent thickness of the infill strut was estimated according to Stafford Smith (1967) [40] and Mainstone (1974) [41], through the following equations.

$$
\frac{w}{d}=0.175 \lambda_{h}^{-0.4} \quad ; \quad \lambda_{h}=\left[\frac{E_{\text {inf }} t_{\text {inf }} \sin (2 \theta)}{4 E_{c} I_{c} H_{\text {inf }}}\right]^{\frac{1}{4}}
$$

The ratio between the equivalent thickness $(w)$ and the length $(d)$ of the strut is expressed as a function of the relative stiffness $\lambda_{\mathrm{h}}$, which depends on Young's Modulus of both infill $\left(E_{\text {inf }}\right)$ and columns $\left(E_{c}\right)$, thickness $\left(t_{\text {inf }}\right)$ and height $\left(H_{\text {inf }}\right)$ of the infill panel, moment of inertia of r.c. columns $\left(I_{c}\right)$, and infill diagonal inclination $(\theta)$.

Due to the lack of experimental tests to calibrate the constitutive law of masonry infill struts, the model proposed by Panagiotakos and Fardis was assumed [42]. The infill strut constitutive law is shown in Figure $4 b$.

Results of the eigenvalue analysis are reported in Table 1 for the first three vibration modes. The infilled frame model has lower vibration periods and presents lower torsional deformation. Hence, the presence of infills, besides increasing the stiffness of the model, regularizes it.

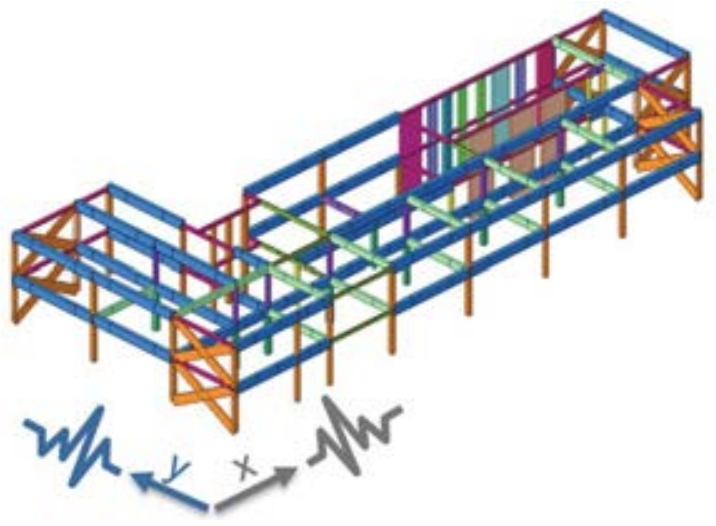

a)

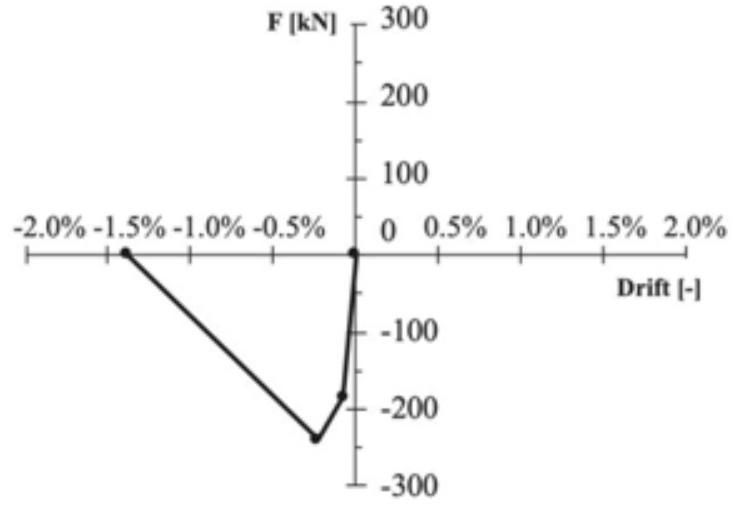

b)

Figure 4: a) F.E. model with infills and b) infill strut constitutive law.

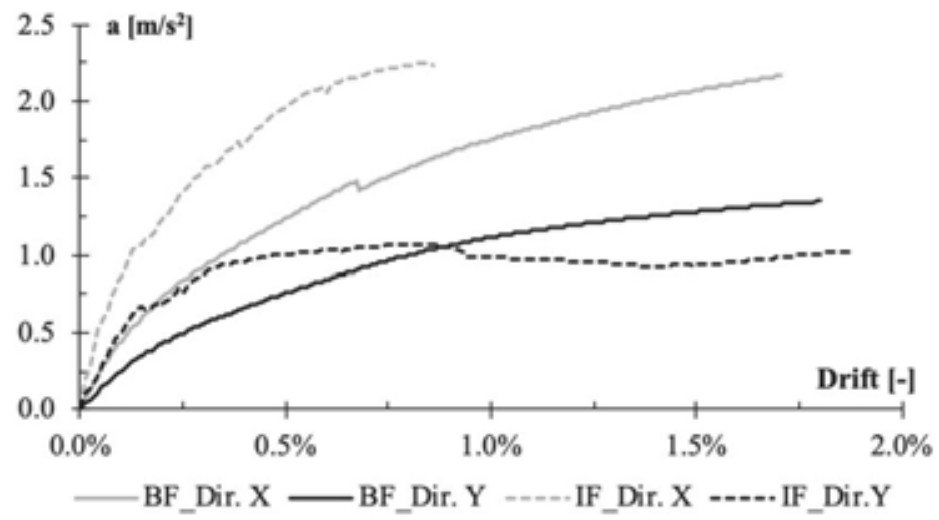

Figure 5: Results of non-linear static analyses for BF and IF models. 


\begin{tabular}{|c|c|c|c|c|c|c|c|c|}
\hline \multirow[b]{2}{*}{ Mode } & \multicolumn{4}{|c|}{ Bare frame model } & \multicolumn{4}{|c|}{ Infilled frame model } \\
\hline & $T[s]$ & $m_{T x}[\%]$ & $m_{T y}[\%]$ & $m_{R z}[\%]$ & $T[s]$ & $m_{T x}[\%]$ & $m_{T y}[\%]$ & $m_{R z}[\%]$ \\
\hline 1 & 1.111 & - & 81.93 & - & 0.844 & - & 87.58 & - \\
\hline 2 & 1.037 & - & - & 81.40 & 0.708 & 26.32 & - & 62.62 \\
\hline 3 & 0.758 & 82.32 & - & - & 0.592 & 60.92 & - & 27.56 \\
\hline
\end{tabular}

Table 1: Dynamic properties for first three vibration modes.

A preliminary non-linear static analysis (NLSA) was performed on the model to evaluate the response of both bare and infilled frame in the two main directions. Capacity curves resulting from NLSA are reported in Figure 5 in terms of acceleration (i.e., base shear normalized with respect to building mass) and global drift (i.e., top displacement normalized with respect to building heigh). As it can be expected, X-direction has a higher stiffness than Ydirection, which instead appears to be more ductile even in the IF configuration. The effect of infills is more evident for X-direction (which presents three infilled bays) than for Y-direction (two infilled bays).

\subsection{Definition of ground motion records}

The selection of ground motion suites was carried out through the procedure Select\&Match, proposed by Paolucci et al. [43], with the aim of providing a large set of input ground motion records for a wide range of intensity levels to be used for the derivation of site-independent fragility curves. For this purpose, a target spectrum referring to the site of L'Aquila, Italy, for increasing return periods (i.e., 50, 100, 200, 475, 975, 2475, and 5000 years) was defined to select ground motions of increasing intensity. A suite of ten spectrum-similar ground motion records was defined for each reference return period, with a similarity criteria less strict than the code-compliant spectrum compatibility $[44,45]$, in order to define site-independent ground motion sets.

The values of peak ground acceleration (PGA) of the selected ground motions are reported in Figure 6, compared to PGAs of the reference spectrum, for increasing return periods. A higher dispersion can be observed for greater return periods.

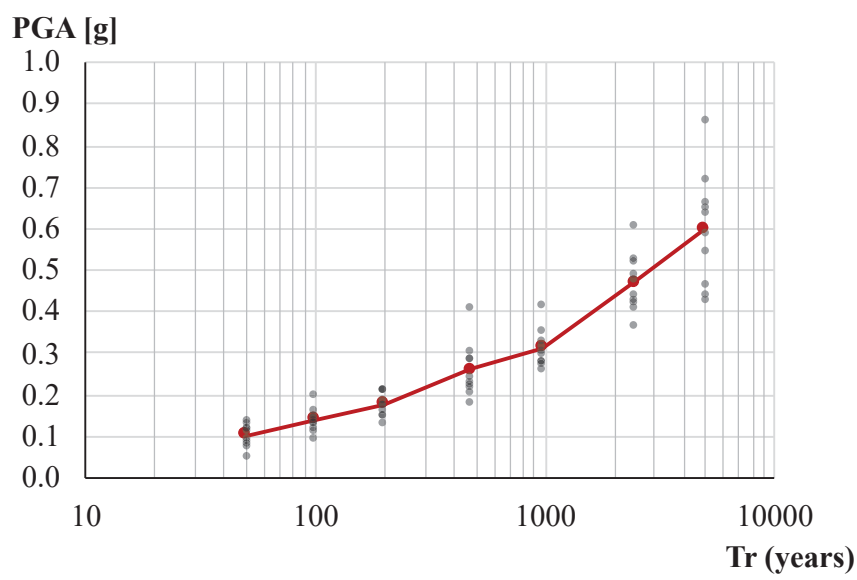

Figure 6: PGAs of selected accelerograms (grey) compared to PGAs of reference spectrum (red).

Seventy accelerograms were selected and applied to models (both BF and IF) separately in the two main directions, in order to more clearly associate each level of PGA to the investigated engineering demand parameter (EDP). Thus, for each model, 140 NLTHA were carried out. 


\subsection{Definition of the EDP}

Fragility assessment by means of numerical analyses requires the definition of reference demand parameters, which should have a good correlation with damage. In this case, the maximum interstory drift ratio (IDR) was selected to describe both structural and non-structural damage, as reported in the macro-seismic scale EMS98 [46] for five increasing damage states (DSs).

Research in the field of fragility curves for existing reinforced concrete buildings has proposed IDR thresholds to distinguish between DSs which can be reached and exceeded by a structure: slight damage, moderate damage, severe damage, partial collapse and complete collapse. Masi et al. [9] proposed five IDR thresholds in r.c. frames designed for gravitational loads only, considering both structural and non-structural elements. The correlation between IDR thresholds and DSs was evaluated by means of parametric non-linear dynamic analyses, where the global damage was quantified in terms of ductility demand and capacity of structural elements.

More recently, the observation of RC buildings damaged by seismic events led to the definition of IDR thresholds which take into account the seismic response of infills for the first three DSs. An extended review and processing of the available experimental data from the literature, in terms of drift capacity of infill panels, was presented in Del Gaudio et al. [25], providing novel median IDR capacities, which were then validated based on the assessment of losses caused by the L'Aquila earthquake [47].

Table 2 compares IDR thresholds from the aforementioned studies. It can be observed that the first set is more conservative for the second, third, and fourth limits, thus including the exceeding of DSs by infill panels of the second proposed set. Thus, in the present study, the IDR thresholds were assumed according to Masi et al. [9], expect for the first threshold which resulted to be more conservative according to Del Gaudio et al. [25]

A shortcoming of this selected set is that the same IDR thresholds were assumed for both $\mathrm{BF}$ and IF models, even though different modelling strategies affect the development of story displacements. The difference mainly regards lower DSs, while it tends to decrease for higher DSs, where the contribution of infills is strongly reduced. Further investigations are needed to evaluate the most suitable set of thresholds, distinguishing between BF and IF model. In this framework, $\mathrm{BF}$ model is here presented only for comparison purposes.

\begin{tabular}{|c|c|c|c|c|c|}
\hline & $\mathrm{DS}_{0}$ & $\mathrm{DS}_{1}$ & $\mathrm{DS}_{2}$ & $\mathrm{DS}_{3}$ & $\mathrm{DS}_{4}$ \\
\hline Masi et al. [9], & $0.1 \%$ & $0.25 \%$ & $0.5 \%$ & $1.0 \%$ & $2.5 \%$ \\
\hline Del Gaudio et al. [25] & $0.08 \%$ & $0.32 \%$ & $0.94 \%$ & $1.78 \%$ & 6 \\
\hline Selected IDR & $0.08 \%$ & $0.25 \%$ & $0.5 \%$ & $1.0 \%$ & $2.5 \%$ \\
\hline
\end{tabular}

Table 2: IDR thresholds for five damage states for RC frames designed for gravitational loads only.

\subsection{Derivation of fragility curves}

The outcomes of NLTHA are presented in Figure 7 using cloud plots, reporting each resulting maximum interstory drift ratio associated with the PGA that generated it, with the indication of IDR thresholds.

The BF model shows higher IDR values associated to ground motions of moderate intensity compared to IF model, thus more realizations overcome IDR thresholds for $\mathrm{DS}_{3}$ and $\mathrm{DS}_{4}$. As a consequence, the $\mathrm{DS}_{3}$ threshold in particular is exceeded in advance in the BF model, as it will become evident from the comparison of the derived fragility curves. The most populated damage state for $\mathrm{BF}$ configuration results to be $\mathrm{DS}_{4}$ (partial collapse). On the contrary, infilled model appears to have a lower general dispersion, and more homogeneously populated 
DSs. For the selected seismic input, no NLTHA provides a maximum IDR smaller than the first threshold $\left(\mathrm{DS}_{0}\right)$.

NLTHA results falling between two IDR thresholds represent the cases in which the building reached or exceeded the DS enclosed by the thresholds. PGA values for each IDR range were processed in order to estimate parameters of fragility curves (i.e., log-normal CDF), expressed as follows:

$$
P\left(D \geq D S_{i} \mid P G A\right)=\Phi\left[\frac{\ln \left(P G A / \mu_{D S_{i}}\right)}{\beta_{D S_{i}}}\right]
$$

where $P\left(D \geq D S_{i} \mid P G A\right)$ indicates the conditional probability of exceeding a damage state $D S_{i}$ given a PGA value, $\Phi$ is the standardized normal CDF, and $\mu_{D s i}$ and $\beta_{D s i}$ are the parameters of the CDF (i.e., the median value and the logarithmic standard deviation, respectively).



a)

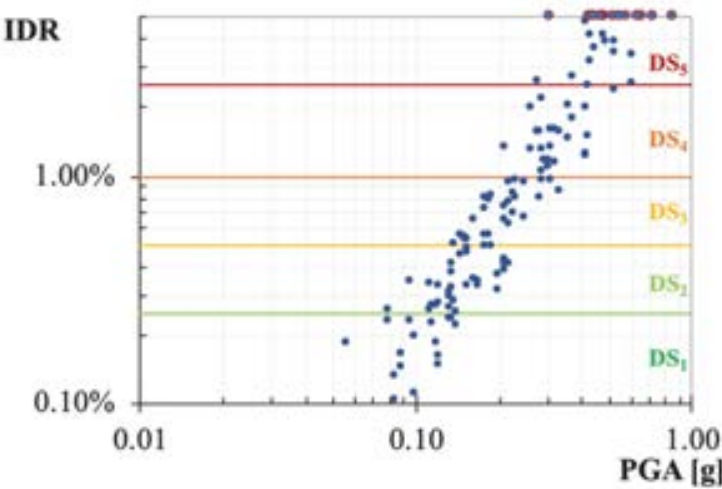

b)

Figure 7: Cloud plots of resulting maximum IDR associated with generating PGA for a) BF and b) IF.

The standard deviation of the proposed fragility curves was computed through the SRSS (i.e., Square Root of Sum of Squares) combination of three different component: i) $\beta_{D}$ expressing dispersion due to record-to-record variability; ii) $\beta_{C}$ related to uncertainties associated to structural capacity, assumed equal to 0.3 according to HAZUS-FEMA [48] for Pre-Code buildings; and iii) $\beta_{M(D S)}$ related to uncertainties in the estimation of median value of EDP thresholds for each DS, assumed equal to 0.4 according to HAZUS-FEMA [48].

$$
\beta_{D S_{i}}=\sqrt{\beta_{D}^{2}+\beta_{C}^{2}+\beta_{M(D S)}^{2}}
$$

The estimation of the probability of exceedance towards global collapse by means of mechanical models might be affected by convergence problems which can be expected in strongly non-linear field [49]. According to the proposal by Jalayer et al. [50], it was assumed that $\mathrm{DS}_{5}$ is reached through two separate conditions: i) IDR greater than the last threshold (i.e., $2.5 \%$ ), identified hereinafter as $N o C$ cases, since the model did not numerically "collapse"; or ii) dynamic instability (due to large displacements as well as failed convergence of the software) [51], identified hereinafter as $\mathrm{Col}$ cases. Both conditions contributed to derive the $\mathrm{DS}_{5}$ fragility curve, estimated by implementing the following equation based on total probability theorem:

$$
P\left(D \geq D S_{5} \mid P G A\right)=P\left(D \geq D S_{5} \mid P G A, N o C\right)(1-P(C o l \mid P G A))+P(C o l \mid P G A)
$$


NLTHA results for which dynamic instability occurred are shown in Figure 7 with a red border, and their probability of occurrence was computed through a logistic regression model. Please refer to Jalayer et al. [50] for further details.

The derived fragility curves are shown in Figure 8, which compares, for both BF and IF models, probability functions with logarithmic standard deviation for either record-to-record variability or all the dispersion components. The values of the estimated parameters are reported in Table 3. Figure 9 provides a comparison between BF and IF models in terms of plotted fragility curves and trend of median value $\mu_{D s i}$.

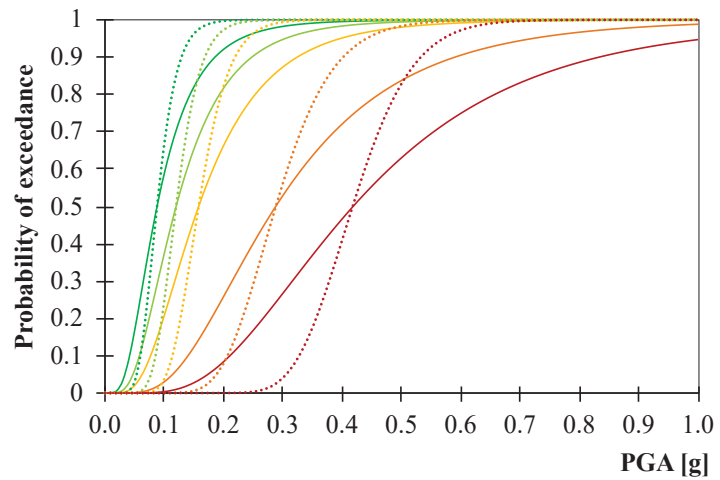

a) DS

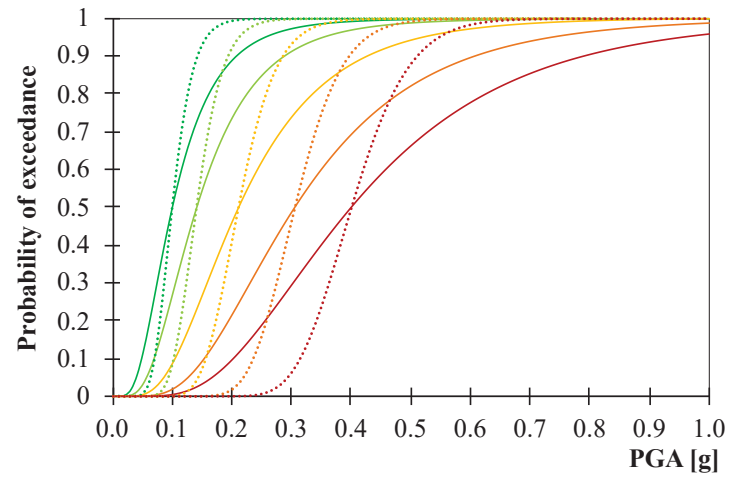

b)

$\mathrm{DS}_{4}$ DSs

Figure 8: Fragility curves derived from a) BF and b) IF models.



a) DS 1

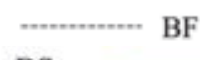

DS2

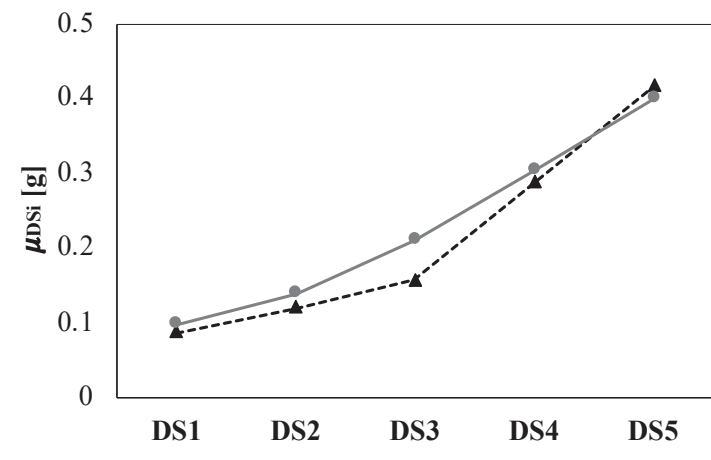

b)

IF

DS 4

DSs

Figure 9: Comparison between BF and IF models in terms of a) fragility curves and b) median value $\mu_{D s i}$.

Bare frame model

Infilled frame model

\begin{tabular}{ccccccc} 
& $\mu_{D s i}$ & $\beta_{D}$ & $\beta_{D s i}$ & $\mu_{D s i}$ & $\beta_{D}$ & $\beta_{D s i}$ \\
\hline $\mathrm{DS}_{1}$ & 0.088 & 0.300 & 0.583 & 0.099 & 0.278 & 0.572 \\
$\mathrm{DS}_{2}$ & 0.120 & 0.265 & 0.566 & 0.140 & 0.250 & 0.559 \\
$\mathrm{DS}_{3}$ & 0.158 & 0.256 & 0.562 & 0.211 & 0.236 & 0.553 \\
$\mathrm{DS}_{4}$ & 0.288 & 0.259 & 0.563 & 0.305 & 0.203 & 0.540 \\
$\mathrm{DS}_{5}$ & 0.417 & 0.190 & 0.535 & 0.400 & 0.189 & 0.535 \\
\hline
\end{tabular}

Table 3: Estimated median values and logarithmic standard deviations. 
Infilled frame model showed a more homogeneously distributed behavior, with regular distance between different DSs. On the contrary, outcome from bare frame model provided the anticipation of the first three DSs, which can be related to threshold values not adapted to the BF configuration.

Results suggest a slightly more ductile behavior of the BF configuration, with a greater distance among DS curves, in accordance with both results of aforementioned NLSA and previous studies $[52,53]$.

\section{CONCLUSIONS}

- The present paper has discussed the derivation of fragility curves for a macro-class of school buildings starting from a representative prototype building. The case study is a two-story r.c. frame school, built in the 1960s and designed for gravitational loads only.

- The fiber model of both the bare frame and infilled frame configurations were developed through Midas Gen software [28] to implement a series of non-linear time history analyses. For the IF configuration a single-strut macro-model of the infills was implemented. Due to the significant presence of openings, only five bays on each story were modelled as infilled.

- A suite of 70 ground motion records was selected based on the procedure proposed by Paolucci et al. [43], based on spectrum-similarity, instead of spectrum-compatibility, in order to obtain a site-independent set.

- The selected ground motions were applied to both BF and IF models in the two main directions and the maximum interstory drift ratio was recorded and chosen as demand parameter, related to the damage state of the structure. IDR thresholds to distinguish among different damage states were assumed according to previous studies from the literature $[9,25]$.

- Results from NLTHA were plotted in terms of maximum IDR and the peak ground acceleration of the ground motion that generated it. The statistical post-processing of resulting cloud plot provides the derivation of fragility curves (i.e., log-normal CDF of the probability of exceedance) for five damage states from EMS 98 [46].

- This research contributes to the current knowledge of seismic risk of a relevant class of structures (i.e., school buildings). This contribution will be part of a study that aims to develop maps of seismic risk and damage scenario for Italian school asset, thanks to the IRMA platform [54], specifically developed by Eucentre for this purpose.

\section{ACKNOWLEDGEMENTS}

Special thanks are due to the Italian Department of Civil Protection (DPC), which funded this study in the framework of the ReLUIS-DPC Project 2019-2021 - Work Package 4: MARS (MAps of Risk and Scenarios of seismic damage) - Task 7: Fragility models and curves for schools and other strategic or relevant buildings. A special thanks to the Work Group for the effective cooperation, especially to the task coordinators, Prof. Serena Cattari and Prof. Angelo Masi. 


\section{REFERENCES}

[1] M. Dolce, A. Prota, B. Borzi, F. da Porto, S. Lagomarsino, G. Magenes, C. Moroni, A. Penna, M. Polese, E. Speranza, G.M. Verderame, G. Zuccaro, Seismic risk assessment of residential buildings in Italy, Bull. Earthq. Eng., 2020. https://doi.org/10.1007/s10518-020-01009-5.

[2] F. da Porto, M. Donà, A. Rosti, M. Rota, S. Lagomarsino, S. Cattari, B. Borzi, M. Onida, D. De Gregorio, F. L. Perelli, C. Del Gaudio, P. Ricci, E. Speranza. Comparative analysis of the fragility curves for Italian residential masonry and RC buildings, Bull. Earthq. Eng., 2021. https://doi.org/10.1007/s10518-021-01120-1.

[3] M. Donà, L. Bizzaro, F. Carturan, F. da Porto, Effects of business recovery strategies on seismic risk and cost-effectiveness of structural retrofitting for business enterprises, Earthq. Spectra. 35, 2019 1795-1819. https://doi.org/10.1193/041918EQS098M.

[4] F. Braga, R. Gigliotti, G. Monti, F. Morelli, C. Nuti, W. Salvatore, I. Vanzi, Speedup of post earthquake community recovery: the case of precast industrial buildings after the Emilia 2012 earthquake, Bull. Earthq. Eng. 12, 2014 2405-2418. https://doi.org/10.1007/s10518-014-9583-3.

[5] M. Mazzocchi, A. Montini, Earthquake effects on tourism in Central Italy, Ann. Tour. Res. 28, 2001, 1031-1046. https://doi.org/10.1016/S0160-7383(01)00008-1.

[6] D. Perrone, G.J. O’Reilly, R. Monteiro, A. Filiatrault, Assessing seismic risk in typical Italian school buildings: From in-situ survey to loss estimation, Int. J. Disaster Risk Reduct. 44, 2020, 101448. https://doi.org/10.1016/j.ijdrr.2019.101448.

[7] M. Di Ludovico, A. Digrisolo, C. Moroni, F. Graziotti, V. Manfredi, A. Prota, M. Dolce, G. Manfredi, Remarks on damage and response of school buildings after the Central Italy earthquake sequence, Bull. Earthq. Eng. 17, 2019, 5679-5700. https://doi.org/10.1007/s10518-018-0332-X.

[8] United Nations, Sendai Framework for Disaster Risk Reduction 2015-2030, Geneva, Switzerland, 2015. https://www.unisdr.org/files/43291_sendaiframeworkfordrren.pdf

[9] A. Masi, S. Lagomarsino, M. Dolce, V. Manfredi, D. Ottonelli, Towards the updated Italian seismic risk assessment: exposure and vulnerability modelling, Bull. Earthq. Eng. 2021. https://doi.org/10.1007/s10518-021-01065-5.

[10] F. Braga, M. Dolce, D. Liberatore, A statistical study on damaged buildings and an ensuing review of the MSK-76 scale., in: Proc. Seventh Eur. Conf. Earthq. Eng., Athens, Greece, 1982.

[11] M. Rota, A. Penna, C.L. Strobbia, Processing Italian damage data to derive typological fragility curves, Soil Dyn. Earthq. Eng. 28, 2008 933-947. https://doi.org/10.1016/j.soildyn.2007.10.010.

[12] C. Del Gaudio, M. Di Ludovico, M. Polese, G. Manfredi, A. Prota, P. Ricci, G.M. Verderame, Seismic fragility for Italian RC buildings based on damage data of the last 50 years, Bull. Earthq. Eng., 2020. https://doi.org/10.1007/s10518-019-00762-6.

[13] M. Vettore, Y. Saretta, L. Sbrogiò, M.R. Valluzzi, A New Methodology for the Survey and Evaluation of Seismic Damage and Vulnerability Entailed by Structural Interventions on Masonry Buildings: Validation on the Town of Castelsantangelo sul Nera (MC), Italy, Int. J. Archit. Herit., 2020 1-26. 
https://doi.org/10.1080/15583058.2020.1766159.

[14] A.J. Kappos, G. Panagopoulos, C. Panagiotopoulos, G. Penelis, A hybrid method for the vulnerability assessment of R/C and URM buildings, Bull. Earthq. Eng. 4, 2006, 391-413. https://doi.org/10.1007/s10518-006-9023-0.

[15] S. Lagomarsino, S. Giovinazzi, Macroseismic and mechanical models for the vulnerability and damage assessment of current buildings, Bull. Earthq. Eng. 4, 2006, 415-443. https://doi.org/10.1007/s10518-006-9024-z.

[16] S. Lagomarsino, S. Cattari, Fragility Function of Masonry Buildings, in: K. Pitilakis, H. Crowley, A.M. Kaynia (Eds.), SYNER-G Typology Defin. Fragility Funct. Phys. Elem. Seism. Risk Build. Lifelines, Transp. Networks Crit. Facil., 2014. https://doi.org/10.1007/978-94-007-7872-6.

[17] M. Donà, P. Carpanese, V. Follador, L. Sbrogiò, F. da Porto, Mechanics-based fragility curves for Italian residential URM buildings, Bull. Earthq. Eng., 2020, 1-34. https://doi.org/10.1007/s10518-020-00928-7.

[18] M. Vettore, M. Donà, P. Carpanese, V. Follador, F. da Porto, M.R. Valluzzi, A Multilevel Procedure at Urban Scale to Assess the Vulnerability and the Exposure of Residential Masonry Buildings: The Case Study of Pordenone, Northeast Italy, Heritage. 3, 2020, 1433-1468. https://doi.org/10.3390/heritage3040080.

[19] C. Del Gaudio, M.T. De Risi, G.M. Verderame, Seismic Loss Prediction for Infilled RC Buildings via Simplified Analytical Method, J. Earthq. Eng., 2021. https://doi.org/10.1080/13632469.2021.1875940.

[20] B. Borzi, H. Crowley, R. Pinho, Simplified pushover-based earthquake loss assessment (SP-BELA) method for masonry buildings, Int. J. Archit. Herit. 2, 2008, 353-376. https://doi.org/10.1080/15583050701828178.

[21] B. Borzi, R. Pinho, H. Crowley, Simplified pushover-based vulnerability analysis for large-scale assessment of RC buildings, Eng. Struct. 30, 2008, 804-820. https://doi.org/10.1016/j.engstruct.2007.05.021.

[22] G. Tecchio, M. Donà, C. Modena, Direct displacement-based design accuracy prediction for single-column RC bridge bents, Earthq. Struct. 9, 2015, 455-480. https://doi.org/10.12989/eas.2015.9.3.455.

[23] A. Masi, Seismic vulnerability assessment of gravity load designed R/C frames, Bull. Earthq. Eng. 1, 2003, 371-395. https://doi.org/10.1023/B:BEEE.0000021426.31223.60.

[24] A. Masi, A. Digrisolo, V. Manfredi, Fragility curves of gravity-load designed RC buildings with regularity in plan, Earthq. Struct. 9, 2015, 1-27. https://doi.org/10.12989/eas.2015.9.1.001.

[25] C. Del Gaudio, M.T. De Risi, P. Ricci, G.M. Verderame, Empirical drift-fragility functions and loss estimation for infills in reinforced concrete frames under seismic loading, Bull. Earthq. Eng., 2019. https://doi.org/10.1007/s10518-018-0501-y.

[26] L. 23/1996: Regulation for School Buildings, Off. Gazzette Ital. Repub. N¹5 19th January 1996. Rome, Italy. (1996) (in Italian).

[27] A. Masi, A. Digrisolo, G. Santarsiero, Analysis of a large database of concrete core tests with emphasis on within-structure variability, Materials (Basel). 12, 2019. https://doi.org/10.3390/ma12121985. 
[28] MIDAS Information Technology Co., Midas Gen, (n.d.). www.cspfea.net.

[29] E. Spacone, F.C. Filippidou, F.F. Taucer, Fibre beam-column model for non-linear analysis of rc frames: Part I. Formulation, Earthq. Eng. Struct. Dyn. 25, 1996, 711-725.

[30] J.B. Mander, M.J.N. Priestley, R. Park, Theoretical Stress-Strain Model for Confined Concrete, J. Struct. Eng. 114, 1988, 1804-1826.

[31] M. Menegotto, P.E. Pinto, Method of analysis for cyclically loaded RC plane frames including changes in geometry and non-elastic behaviour of elements under combined normal force and bendin, in: Symp. Resist. Ultim. Deform. Struct. Acted by Well Defin. Loads, International Association for Bridge and Structural Engineering, Zurich, Switzerland, 1973.

[32] G.M. Calvi, D. Bolognini, Seismic response of reinforced concrete frames infilled with weakly reinforced masonry panels, J. Earthq. Eng. 5, 2001, 153-185. https://doi.org/10.1080/13632460109350390.

[33] S. Hak, P. Morandi, G. Magenes, T.J. Sullivan, Damage control for clay masonry infills in the design of RC frame structures, J. Earthq. Eng. 16, 2012, 1-35. https://doi.org/10.1080/13632469.2012.670575.

[34] M. Minotto, N. Verlato, M. Donà, F. da Porto, Strengthening of In-Plane and Out-ofPlane Capacity of Thin Clay Masonry Infills Using Textile- and Fiber-Reinforced Mortar, J. Compos. Constr. 24, 2020. https://doi.org/10.1061/(asce)cc.1943-5614.0001067.

[35] P. Morandi, S. Hak, G. Magenes, Performance-based interpretation of in-plane cyclic tests on RC frames with strong masonry infills, Eng. Struct. 156, 2018, 503-521. https://doi.org/10.1016/j.engstruct.2017.11.058.

[36] F. da Porto, M. Donà, N. Verlato, G. Guidi, Experimental Testing and Numerical Modeling of Robust Unreinforced and Reinforced Clay Masonry Infill Walls, With and $\begin{array}{lllll}\text { Without } & \text { Openings, } & \text { Front. Built }\end{array}$ https://doi.org/10.3389/fbuil.2020.591985.

[37] M. Donà, M. Minotto, E. Saler, G. Tecchio, F. da Porto. Combined in-plane and out-ofplane seismic effects on masonry infills in RC frames, in: Ing. Sismica, 2017: pp. 157173.

[38] F. Mazza, A. Donnici, In-plane and out-of-plane seismic damage of masonry infills in existing r.c. structures: the case study of De Gasperi-Battaglia school in Norcia, Bull. Earthq. Eng., 2021. https://doi.org/10.1007/s10518-020-00981-2.

[39] F.J. Crisafulli, A.J. Carr, Proposed macro-model for the analysis of infilled frame structures, Bull. New Zeal. Soc. Earthq. Eng. 40, 2007, 69-77. https://doi.org/10.5459/bnzsee.40.2.69-77.

[40] B. Stafford Smith, Methods for predicting the lateral stiffness and strength of multistorey infilled frames, Build. Sci. 2, 1967. https://doi.org/10.1016/00073628(67)90027-8.

[41] R.J. Mainstone, Supplementary note on the stiffnesses and strengths of infilled frames., Build. Res. Establ. Build. Res. Stn. (1974).

[42] T.B. Panagiotakos, M.N. Fardis, Seismic response of infilled RC frame structures, in: Proc. 11th World Conf. Earthq. Eng., 1996: pp. 1-8. 
[43] R. Paolucci, A.G. Ozcebe, C. Smerzini, A. Masi, V. Manfredi, Selection and spectral matching of recorded ground motions for earthquake engineering analysis. Overview of the S \& M Matlab code and illustrative example for construction of fragility curves., 2020 (to be published).

[44] Circ 21/01/2019 N.7, Istruzioni per l'applicazione dell' "Aggiornamento delle "Norme tecniche per le costruzioni" di cui al decreto ministeriale 17 gennaio 2018. (Italian Guideline), Suppl. Ordin. Alla “Gazzetta Uff. n. 35 Del 11 Febbraio 2019 - Ser. Gen. 337. (in Italian)

[45] European Committee for Standardization, EN1998 Eurocode 8-1: Design of structures for earthquake resistance. Part 1: General rules, seismic actions and rules for buildings, 144 (2001) 55-60. https://doi.org/10.1680/cien.144.6.55.40618.

[46] G. Grunthal, EMS98 - European Macroseismic Scale 1998, Conseil de l'Europe - Cahiers du Centre Européen de Géodynamique et de Séismologie, Luxemburg, 1998.

[47] C. Del Gaudio, M.T. De Risi, G.M. Verderame, A simplified methodology for seismic repair costs assessment in RC buildings: an application to L'Aquila 2009 event, in: Atti Del XVIII Convegno ANIDIS L'ingegneria Sismica Ital. Ascoli Piceno, 15-19 September 2019.

[48] FEMA - Federal Emergency Management Agency, HAZUS Earthquake Model Technical Manual 4.2 SP3, Washingt. DC. (2020). https://www.fema.gov/.

[49] R. Villaverde, Methods to Assess the Seismic Collapse Capacity of Building Structures: State of the Art, J. Struct. Eng. 133, 2007, 57-66. https://doi.org/10.1061/(asce)07339445(2007)133:1(57).

[50] F. Jalayer, H. Ebrahimian, A. Miano, G. Manfredi, H. Sezen, Analytical fragility assessment using unscaled ground motion records, Earthq. Eng. Struct. Dyn. 46, 2017, 2639-2663. https://doi.org/10.1002/eqe.2922.

[51] D. Vamvatsikos, C. Allin Cornell, Incremental dynamic analysis, Earthq. Eng. Struct. Dyn. 31, 2002, 491-514. https://doi.org/10.1002/eqe.141.

[52] M. Dolšek, P. Fajfar, The effect of masonry infills on the seismic response of a fourstorey reinforced concrete frame - a deterministic assessment, Eng. Struct. 30, 2008, 1991-2001. https://doi.org/10.1016/j.engstruct.2008.01.001.

[53] B. Pantò, I. Caliò, P.B. Lourenço, Seismic safety evaluation of reinforced concrete masonry infilled frames using macro modelling approach, Bull. Earthq. Eng. 15, 2017, 3871-3895. https://doi.org/10.1007/s10518-017-0120-z.

[54] B. Borzi, M. Onida, M. Faravelli, D. Polli, M. Pagano, D. Quaroni, A. Cantoni, E. Speranza, C. Moroni, IRMA platform for the calculation of damages and risks of Italian residential buildings, Bull. Earthq. Eng., 2020. https://doi.org/10.1007/s10518-02000924-X. 